\title{
Trends in Corporal Punishment and Attitudes in Favour of This Practice: Toward a Change in Societal Norms
}

\author{
Marie-Ève Clément \\ Université du Québec en Outaouais \\ Claire Chamberland \\ Université de Montréal
}

\begin{abstract}
Over 10 years ago, Quebec's statistical institute, the Institut de la Statistique du Québec, conducted its first population survey on family violence in the lives of children. Taken again 5 years later (2004), the survey showed a decrease in the use of corporal punishment of children. This paper presents the results of the third survey, which was conducted by telephone in 2012 with a representative sample of 4,029 maternal figures. More specifically, this paper presents the evolution of prevalence rates for corporal punishment and attitudes in favour of this practice as observed between the 3 surveys conducted in 1999, 2004, and 2012. The paper also presents the associations found between mothers' attitudes and their reports of corporal punishment. The results show that attitudes and practices are closely associated and that corporal punishment has been in a constant and significant decrease since 1999, regardless of the children's age. Supported by a decrease in maternal attitudes in favour of this practice, the results are discussed in terms of changes in Quebec's social norms.
\end{abstract}

Keywords: corporal punishment, trends, parental attitudes, epidemiology, child abuse

\section{RÉSUMÉ}

Il y a plus de 10 ans, l'Institut de la statistique du Québec réalisait la première enquête de population sur la violence familiale dans la vie des enfants. Reprise 5 ans plus tard, l'enquête avait montré une diminution du recours aux punitions corporelles envers les enfants. Cet article vise à présenter les résultats de la troisième enquête réalisée en mode téléphonique en 2012 auprès d'un échantillon représentatif de 4029 figures maternelles. Plus particulièrement, l'article présente l'évolution des taux de prévalence des punitions

Marie-Ève Clément, Canadian research chair on violence against children, Département de psychoéducation et de psychologie, Université du Québec en Outaouais; Claire Chamberland, École de service social Université de Montréal.

Correspondence concerning this article should be addressed to Marie-Eve Clément, Université du Québec en Outaouais, campus de Saint-Jérôme, 5 rue Saint-Joseph, Saint-Jérôme, QC J7Z 0B7. Email: marie-eve.clement@uqo.ca 
corporelles et des attitudes en faveur de cette pratique telle qu'observée entre les 3 enquêtes réalisées en 1999, 2004 et 2012. Dans un second temps, l'article montre la présence de liens étroits entre les attitudes maternelles et les conduites de punitions corporelles ainsi qu'une diminution constante et significative du recours aux punitions corporelles envers les enfants, et peu importe leur âge. Appuyées par une diminution des attitudes en faveur de cette pratique, les résultats sont discutés en termes de changements de normes sociales au Québec.

Mots clés : punitions corporelles, tendances, attitudes parentales, épidémiologie, violence faite aux enfants

According to the World Health Organization (Organisation Mondiale de la Santé, 2002) and Unicef (Organisation des Nations-Unies, 2006), violence toward children is defined as the threat or the intentional use of force or power against a child that results in, or risks the result of, injury to the child's health, development, dignity, or even to the child's survival. This definition suggests three important criteria: the presence of a relationship of power; the nature of the acts committed (which can be physical, sexual, and psychological); and the consequences, potential or real, for the child. Over the past few decades, consideration of these criteria has led an increasing number of researchers and professionals to view corporal punishment as a form of violence (American Academy of Pediatrics, 1998; Canadian Paediatric Society, 2004; Clément, 2011; Coalition Canadienne pour les droits des enfant, 2009; Gershoff, 2002; Straus, 2008). Here, it is defined as a physical act committed by an adult in a situation of power, regardless of his or her intention, to cause the child pain or physical discomfort in order to correct or control behaviour that is deemed undesirable (Durrant \& Ensom, 2004; Gershoff, 2002; Straus, 2008; Zolotor, Theodore, Runyan, Chang, \& Laskey, 2011).

Not only does corporal punishment imply a relationship of power, one inherent to the parent-child relationship, but the popular concept of this form of "parental control" has changed a great deal over the past century in Quebec, in Canada, and around the world. Furthermore, we note that a growing number of countries legally prohibit the use of any kind of corporal punishment on children (Zolotor \& Puzia, 2010). From a legal point of view, it is important to remember that in Quebec, the Civil Code provision granting parents the right to use moderate and reasonable corrective measures with their child was abolished 20 years ago. While this right to correct a child was amended on the provincial level, it is still accepted on the federal level (Criminal Code, Section 43) although the Supreme Court of Canada recently defined guidelines to differentiate between reasonable force and abusive force (Durrant, Trocmé, Fallon, Milne, \& Black, 2009).

According to Emery and Laumann-Billings (1998), the threat to the child's development and integrity remains critical when behaviour is qualified as being "violent." While the scientific community is still quite divided on the issue of the effects of corporal punishment (Larzelere, 2000; Paquette, Bigras, \& Crepaldi, 2010), an increasing number of studies illustrate its short- and long-term negative impact on the child. The metaanalysis done by Gershoff (2002) shows, for example, that there are links between corporal punishment and the child's subsequent aggressive antisocial behaviour, poorer internalization of moral values, and mental health problems, as well as deterioration in the quality of the parent-child relationship. The majority of these effects persist into adulthood. The meta-analysis done by Paolucci and Violato (2004) also demonstrates the existence of negative effects, though less severe, on the emotions and behaviours of individuals exposed to instances of corporal punishment. Other longitudinal studies have recently shown similar effects (Grogan-Kaylor, 2004; 
Gershoff, Lansford, Sexton, Davis-Kean, \& Sameroff, 2012; Mulvaney \& Mebert, 2007), and some have even identified negative effects on young children's cognitive abilities (Berlin et al., 2009; Straus \& Paschall, 2009).

In Canada, even though violence is considered to be one of the most important problems affecting a child's development (Afifi, 2011; Jack, 2010), there are still very few populational studies, on either the provincial or the national level, that help estimate the number of child victims annually. Recurrent national monitoring is available through the Canadian Incidence Study (CIS) of reported child abuse and neglect (see Trocmé et al., 2010), but these data concern only the most severe cases reported to protective services. Thus there is still an important shortage of the data necessary to build a better understanding of the number and magnitude of situations occurring in the general population (Jack, 2010).

Two types of research have helped document the extent of corporal punishment within the population. In the first case, researchers questioned adults from the general population in order to document the lifetime prevalence of corporal punishment experienced during childhood (Afifi, Mota, Dasiewicz, MacMillan, \& Sareen, 2012; Tourigny, Gagné, Joly, \& Chartrand, 2006; Tourigny, Hébert, Joly, Cyr, \& Baril, 2008). In the second case, researchers documented the prevalence over a shorter time period, usually 12 months but sometimes even less. These studies are generally conducted with parents from the general population, most often with mothers (Afifi et al., 2012; Clément \& Chamberland, 2007; Fréchette \& Romano, 2012; Straus, Hamby, Finkelhor, Moore, \& Runyan, 1998; Zolotor et al., 2011). As one might expect, the rates reported in these studies are lower than those from lifetime prevalence studies, since the time period covered is shorter. However, from a methodological perspective, these short-term studies are often more rigorous than the lifetime prevalence studies, which present a significant risk of recall bias and which most often produce estimates based on a single item or on questionnaires that have not been validated (e.g., Tourigny et al., 2008).

The annual prevalence rates demonstrate that corporal punishment is a common practice in families. In a Quebec survey conducted in 2004, 43\% of mothers admitted to this practice toward a child on an annual basis (Clément \& Chamberland, 2007). Other Canadian (Fréchette \& Romano, 2012; Oldershaw, 2002) and American (Straus et al., 1998) surveys have obtained similar results. Prevalence rates have been declining. Between 1999 and 2004, the rate dropped from 48\% to 43\% in Quebec (Clément \& Chamberland, 2007). A similar decrease was also observed on the national level. An analysis of eight cycles of the National Longitudinal Survey of Children and Youth (NLSCY) by Fréchette and Romano (2012) showed a decrease varying from $10 \%$ to $20 \%$, depending on the children's age, in corporal punishment between 1994 and 2006. In the United States, an 18\% drop was also observed between 1975 and 2002 (Zolotor et al., 2011).

In short, even if we see a decrease in corporal punishment rates, there are still few studies that track its true development in the population since trend studies require that data be collected during at least three separate periods (Bernard \& Lapointe, 1995). Considering the impact of this kind of violence on the child, such data are essential for reporting on the collective efforts made over the past few decades to prevent its occurrence (Afifi, 2011).

\section{Study Objectives}

First, this paper presents the trend of corporal punishment prevalence rates and attitudes favouring this practice in the population of Quebec's families as observed in three population surveys $(1999,2004,2012)$ covering a 13-year period. Second, it presents the associations found between attitudes toward corporal 
punishment and its practices within the framework of the third populational survey conducted in 2012 (Clément, Bernèche, Chamberland, \& Fontaine, 2013).

\section{METHOD}

\section{Surveys' Descriptions and Samples}

This study's data are taken from three large-scale populational surveys conducted by the Institut de la Statistique du Québec (ISQ) in 1999, 2004, and 2012, which intended to document the prevalence rates and trends of parental attitudes and practices of family violence toward children (Clément, Bouchard, Jetté, \& Laferrière, 2000; Clément, Chamberland, Côté, Dubeau, \& Beauvais, 2005; Clement et al., 2013).

The sampling for the 1999 and 2004 surveys comprised all children aged 0 to 18 living in a private household in Quebec and cohabiting at least $50 \%$ of the time with a woman (mother, stepmother, father's new female partner, female guardian, etc.). The sample was selected on the basis of a survey made up of randomly generated telephone numbers using the Random Digit Dial (RDD) procedure, which covered 95\% of the targeted population of children. For these first two surveys, a polling firm collected the data using Computer Assisted Telephone Interviews (CATI). The surveys provided contact with 2,469 mother figures in 1999 and 3,148 mother figures in 2004; they yielded response rates of $76 \%$ and $57 \%$, respectively. The sample size had to slightly increase between each survey in order to detect small differences in prevalence rates (see Clément et al., 2013).

The third survey, conducted in 2012, provided contact with 4,029 mother figures living $40 \%$ or more of the time (minimum time for shared custody) with a child between 6 months and 18 years old and yielded a 54\% response rate. The decrease in the response rate between the first and the last two surveys did not affect their generalization capacity (see further analysis in Clément et al., 2013). The 2012 survey was conducted following the same procedure used in the earlier ones except for the use of a list from the Régie des Rentes du Québec (RRQ, a program supporting the province's children) to create the sample frame. With the Access to Information Commission's (Commission d'accès à l'information) consent, RRQ gave ISQ a sample frame drawn from the list of children eligible for child assistance (part of Quebec's family policy), which covers $98 \%$ of the population of children targeted by the survey (Clément et al., 2013). Unlike the preceding surveys, children under 6 months old were excluded because the sample frame did not cover them well (e.g., registration deadlines). Analyses showed that changing the sample frame did not alter the analyses comparing the three surveys with respect to the parental behaviours reported (Clément et al., 2013). The decision to survey only women was made because past research has found that they are more likely than men to disclose violence toward children. Furthermore, when the choice is left to the household, women are practically always chosen to answer questions about child discipline strategies (see Clément \& Bouchard, 2005).

The Research Ethics Board of the Quebec Statistics Institute approved the survey, as well as the university's Ethics Board prior to data collection. Furthermore, several steps were taken to ensure respondents' confidentiality, such as informed consent from each respondent obtained before the interview. Information about relevant local services was provided to those who reported being victims of severe violence in their childhood or using severe violent discipline, and to those who expressed distress during the interview. 
A stratified, multistage sampling plan was used to select the sample for the surveys according to various variables such as the presence of at least one child in shared custody in the household, the number of children, the age of the youngest child, and geographic areas. Each respondent was then given a weight corresponding to the number of parents or children they "represented" in the population. Two weights were used and analyses were done accordingly. Results regarding mothers (e.g., attitudes and characteristics) and results regarding children (age, gender, and violence toward them) were obtained with data weighted corresponding to the number of mothers or children they each represented in the target population. These weights were calculated following many steps in order to adjust for selection probabilities, to reduce nonresponse bias, and to adjust for population distribution (see Clément et al., 2000, 2005, 2013). A similar weighting procedure was used in all three surveys to allow for inferences to the population (Institut de la Statistique du Québec, 2011).

Table 1 presents the characteristics of households in all three surveys. First, results indicate a higher percentage of boys in the last two surveys (51\%) compared to the 1999 one (48\%). The age of the children selected varies slightly from one survey to another, the 2004 survey having children a bit older than those conducted in 1999 and 2012. With regard to the parent and household characteristics, the chi-square analyses demonstrate that the families' profiles differ significantly from each other in several respects. For example,

Table 1

Comparisons of Samples in the 1999, 2004, and 2012 Surveys

\begin{tabular}{|c|c|c|c|c|c|}
\hline & 1999 & 2004 & 2012 & \multirow[t]{2}{*}{ Survey comparisons } & \multirow[t]{2}{*}{$p$} \\
\hline & \multicolumn{3}{|c|}{$\%$} & & \\
\hline \multicolumn{6}{|l|}{ Target child's sex } \\
\hline Boy & 48.4 & 51.0 & 51.2 & $(2012=2004)>1999$ & ** \\
\hline \multicolumn{6}{|l|}{ Children's age } \\
\hline Less than 5 years old & 33.1 & 29.3 & 32.4 & $(2012=1999)>2004$ & $* *$ \\
\hline \multicolumn{6}{|l|}{ Parent's age at child's birth } \\
\hline Less than 25 years old & 24.2 & 15.9 & 12.6 & $2012<2004<1999$ & *** \\
\hline \multicolumn{6}{|l|}{ Education } \\
\hline High school or less & 57.0 & 31.8 & 19.9 & $2012<2004<1999$ & *** \\
\hline \multicolumn{6}{|l|}{ Working status } \\
\hline Not working & 32.5 & 25.4 & 18.0 & $2012<2004<1999$ & *** \\
\hline \multicolumn{6}{|l|}{ Family type } \\
\hline Single parent (mother) & 14.6 & 14.9 & 19.7 & $2012>(2004=1999)$ & $* * *$ \\
\hline \multicolumn{6}{|l|}{ Perceived income } \\
\hline Poor/very poor & 12.7 & 7.7 & 7.1 & $(2012=2004)<1999$ & *** \\
\hline \multicolumn{6}{|l|}{ Family income } \\
\hline Less than $\$ 25,000$ & 21.0 & 7.5 & 9.7 & $2004<2012<1999$ & *** \\
\hline \multicolumn{6}{|l|}{ Social support index } \\
\hline Low level & -- & 24.9 & 18.9 & $2012<2004$ & *** \\
\hline
\end{tabular}

Note. ${ }^{* *} p<.01 .{ }^{* * *} p<.001$. 
fewer mother figures in the 2012 survey were under 25 years old at the child's birth (12.6\%) compared to the surveys from 2004 (15.9\%) and 1999 (24.2\%). Moreover, in 2012 more mother figures reported that they were educated and employed. On the family level, we find slightly more single parents (mother) in 2012 (19.7\%) than in 2004 and 1999 (14.6\% and 14.9\%). The perceived family income (e.g., comfortable/sufficient versus poor/very poor) was also poorer in 1999 than it was in the two more recent surveys. Finally, according to the social support index, measured in the last two surveys with the Social Provision Scale (Caron, 1996; Cutrona, 1984), mothers reported a higher level of social support in 2012 than in 2004. With the exception of the aforementioned index, the cohorts' differences are representative of socioeconomic trends observed in Quebec since the end of the 1990s (Institut de la Statistique du Québec, 2009, 2013).

\section{Questionnaire}

Parental attitudes. The questionnaire used for the three surveys included questions on general attitudes toward violence in childrearing (e.g., "Some children need to be slapped so that they will learn a lesson."). For each question, the choice of answers ranged from 1 (strongly agree) to 4 (strongly disagree). These items were adapted from the Adult-Adolescent Parenting Inventory (Bavoleck, 1984). Mothers' awareness of the impact of psychological aggression and minor physical assault on children was assessed in all three surveys using two items developed by Daro and Gelles (1992; Daro, 1998). For example, respondents were asked, "How often do you think children can be physically injured after their parents administer physical punishment to discipline them?" Responses were evaluated using a 4-point Likert scale, ranging from very often to never.

In the 2004 and 2012 surveys, two questions were added to document the perceived effectiveness of corporal punishment and the level of approval for a law permitting the use of force in childrearing. Four other questions helped determine the extent to which the mother cited the child and the child's behaviour as justification for using physical violence (e.g., "It would be acceptable for a parent to slap a child who is being disobedient."). These questions were drawn from the Justification of Parental Violence Scale, an instrument whose psychometric properties have already been validated within a Quebec population (Fortin, Chamberland, \& Lachance, 2000; Fortin \& Lachance, 1996). The same range of answers (1 to 4) was used for all these questions. Since these questions were added to the last two surveys, there were no comparable items on the 1999 survey.

Corporal punishment toward children. The revised version of the Conflict Tactics Scales, the ParentChild Conflict Tactics Scales (PCCTS; Straus et al., 1998), was used to assess the annual prevalence rates of corporal punishment toward children (minor physical violence subscale). This instrument is the most frequently used in epidemiological research on violence against children, and the most recent version has been validated with a nationally representative American sample (Straus et al., 1998).

Modifications made to the original instrument in the 1999 survey were conserved in the 2004 and 2012 surveys. First, two items were removed from the original "minor physical violence" subscale because of their apparent severity according to the last survey in Quebec ("slapping the child in face, head or ears" and "hit the child on the bottom with a belt, a stick or other hard object"; Clément et al., 2000). Similarly, an American telephone survey showed that among behaviours qualified as child abuse, responders included "spanking the child with a belt, stick or other object" and "slapping the child in the face" (Bensley et al., 
2004). Second, in order to meet the survey's primary goal of documenting annual prevalence rates and trends in violence toward Quebec's children, the PCCTS question did not specifically ask about the mother's own practices, but about those of any adult in the household (e.g. "How many times has any adult of the household, 18 years or older, shouted, yelled or screamed at the child?"). The Corporal Punishment Scale (also called Minor Violence Scale; Straus et al., 1998) thus includes a total of four items that indicate behaviours such as spanking; slapping on the hand, leg, or arm; pinching; and shaking the children. The overall prevalence rate indicates whether the mothers reported at least one of the practices described in each of the behaviours over the 12-month period covered by the survey (see Table 2). The comparisons of parental practices and attitudes between the three surveys were estimated with chi-square tests with second order adjustment.

\section{RESULTS}

\section{Trends in Corporal Punishment Prevalence}

The comparison of the results from the 2012 survey with those obtained in 2004 and 1999 shows that the corporal punishment prevalence rate has significantly changed over a 13-year period in Quebec $(p<.001)$. The downtrend seen between the 1999 and 2004 surveys continued in 2012 with a significant decrease in the percentage of children who experienced at least one episode of corporal punishment during the course of the year. While in $1999,47.7 \%$ of children were subjected to this kind of practice by an adult in the household and $42.9 \%$ were in $2004,34.7 \%$ of Quebec children were so treated in 2012 (see total in Figure 1). A significant trend in the repeated report of annual corporal punishment (three times or more) is also seen between the 2012 survey and the 2004 and 1999 ones. In 2012, 11.4\% children experienced repeated corporal punishment in the last year, which is significantly lower than what was observed in 2004 $(17.1 \%)$ and in $1999(16.4 \% ; p<.001)$.

When the comparison is made according to the children's age categories, the results show that the rates are also all significantly different $(p<.01)$ between the three surveys. Preschool children $(0-5$ years old) experienced less corporal punishment in 2012 (47.8\%) than they did in 2004 (54.9\%) or in $1999(59.9 \%)$. The same observation can be made for school-aged children (6-11 years old), who experienced less corporal punishment in $2012(40.8 \%)$ than they did in 2004 (47\%) or in $1999(59.1 \%)$. Similarly, adolescents (12 years and up) experienced less corporal punishment in $2012(17.4 \%)$ than they did in $2004(23.2 \%)$ or in 1999 (25.8\%; Figure 1).

In 2012, corporal punishment was experienced by more than one third of children (34.7\%) on at least one occasion during the year. When examined individually, we found that these corporal punishments most often took the form of slapping the child's hand, arm, or leg $(26.2 \%)$; spanking the bottom with a bare hand (14.5\%); or shaking a child age 2 or older $(10.7 \%)$. When the comparison is made across surveys, the results show that these kinds of behaviours decreased over time. In fact, there were significantly fewer children $(p<.01)$ who were spanked on the bottom with a bare hand in $2012(14.5 \%)$ as compared to $2004(20.1 \%)$ and $1999(22.7 \%)$, and who were slapped on the hand, leg, or arm in $2012(26.2 \%)$ as compared to 2004 (32.6\%) and 1999 (35.8\%). There were also fewer children aged 2 and up who were shaken in $2012(10.7 \%)$ than there were in $2004(15 \%)$ or in $1999(20.3 \%)$. The only behaviour showing no significant difference $(p=.72)$ between the three surveys was pinching the child: the rate of children subjected to this behaviour has remained stable for 13 years (about 2\%; Figure 2). 


\section{Figure 1}

\section{Trends in Corporal Punishment Rates by Years of Surveys and Children's Ages}

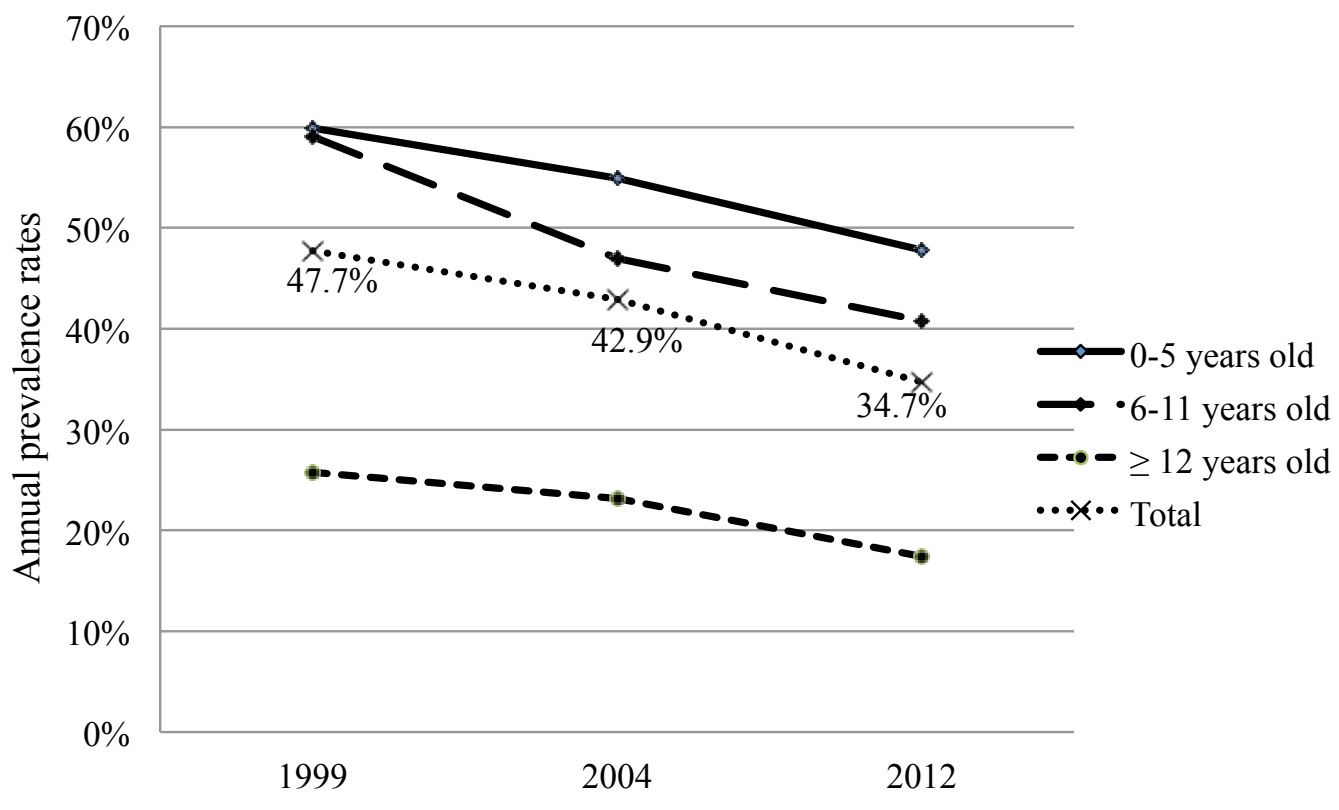

Figure 2

Trends in Corporal Punishment Behaviours Rates by Years of Surveys

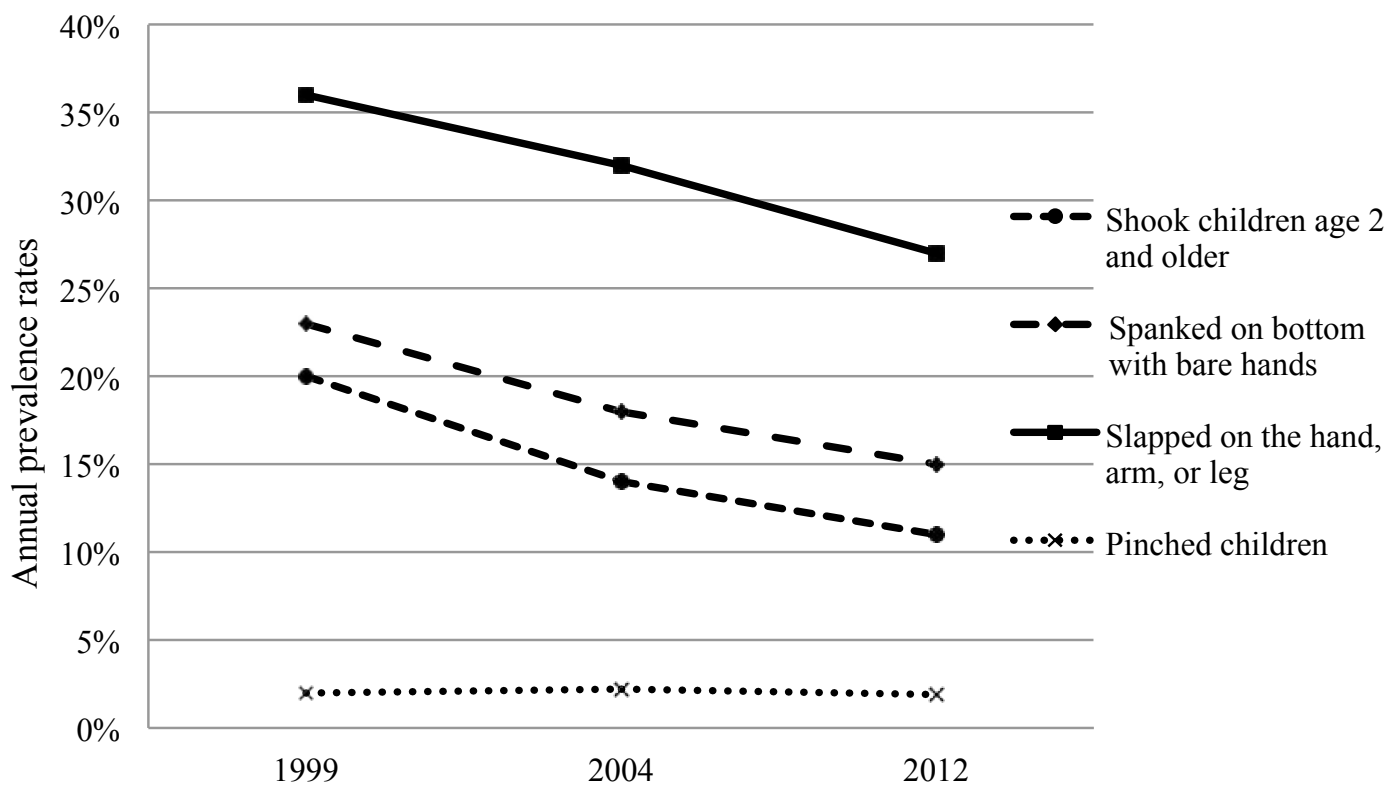




\section{Trends in Attitudes Toward Corporal Punishment}

Results on attitudes toward corporal punishment show that the percentage of mothers favouring this method has significantly decreased since 1999 (Table 2). Thirteen years ago, about $29.2 \%$ of mothers agreed or strongly agreed that some children need to be slapped to learn to behave properly as compared to $25.7 \%$ in 2004 and $15 \%$ in 2012. As well, while in the first survey, approximately $40 \%$ of mothers believed that parents who slap their children are wrong to do so, the percentage grew to $44.9 \% 5$ years later and remained at about the same level in 2012 (43.5\%). Despite this change, we note that in 2012 and 2004, there were still more mothers believing that parents in Quebec are too easy on their children $-80.5 \%$ and $80.5 \%$, respectively - than there were in 1999 (76.7\%).

Table 2

Trends in Parental Attitudes Toward Corporal Punishment

\begin{tabular}{|c|c|c|c|c|c|}
\hline & 1999 & 2004 & 2012 & \multirow[t]{2}{*}{ Survey comparison } & \multirow[t]{2}{*}{$p$} \\
\hline & \multicolumn{3}{|c|}{$\%$} & & \\
\hline $\begin{array}{l}\text { In general, Quebec parents are too soft on their } \\
\text { children }\end{array}$ & 76.7 & 80.5 & 80.5 & $(2012=2004)>1999$ & *** \\
\hline It's wrong for parents to slap their children & 40.4 & 44.9 & 43.5 & $(2012=2004)>1999$ & *** \\
\hline $\begin{array}{l}\text { Some children need to be slapped so that they will } \\
\text { learn a lesson }\end{array}$ & 29.2 & 25.7 & 15.0 & $2012<2004<1999$ & *** \\
\hline $\begin{array}{l}\text { There should be a law allowing parents to use force to } \\
\text { discipline their children }\end{array}$ & -- & 15.7 & 11.6 & $2012<2004$ & *** \\
\hline Spanking is an effective way of disciplining children & -- & 11.8 & 7.6 & $2012<2004$ & *** \\
\hline $\begin{array}{l}\text { It would be acceptable for a parent to slap a child if the } \\
\text { child has provoked it }\end{array}$ & -- & 23.7 & 12.4 & $2012<2004$ & *** \\
\hline $\begin{array}{l}\text { It would be acceptable for a parent to slap a child if the } \\
\text { child is being disobedient }\end{array}$ & -- & 20.0 & 10.3 & $2012<2004$ & *** \\
\hline $\begin{array}{l}\text { It would be acceptable for a parent to slap a child if the } \\
\text { child is being violent }\end{array}$ & -- & 24.9 & 13.9 & $2012<2004$ & $* * *$ \\
\hline $\begin{array}{l}\text { Children can (often or very often) be physically injured } \\
\text { after their parents administered corporal punishment }\end{array}$ & 35.8 & 40.6 & 33.0 & $2012<1999<2004$ & *** \\
\hline $\begin{array}{l}\text { Children can (often or very often) develop } \\
\text { psychological problems that can last a long time } \\
\text { because their parents repeatedly yell at or swear at } \\
\text { them }\end{array}$ & 72.9 & 75.9 & 76.5 & $(2012=2004)>1999$ & *** \\
\hline
\end{tabular}

Note. ${ }^{* * *} p<.001$. 
For two other attitudes toward corporal punishment and for parental attributions, comparisons can only be made between the last two surveys. All the results point in the same direction, namely that in 2012, mothers more repudiated resorting to corporal punishment and citing the child's behaviour as justification for this violence than in 2004. Approximately $12 \%$ of mothers (versus $15.7 \%$ in 2004 ) thought that the law should allow parents to employ force to correct a child, and $7.6 \%$ (versus $11.8 \%$ in 2004) considered spanking to be an effective method of disciplining children (Table 2). With respect to attributive attitudes, we observe that in 2012, a significantly lower percentage of Quebec mothers considered it acceptable to slap a child who is misbehaving: $12.4 \%$ of mothers agreed or strongly agreed that slapping is justified if the child is defiant as compared to $23.7 \%$ in $2004,10.3 \%$ in 2012 as compared to $20 \%$ in 2004 if the child is disobedient, and $13.9 \%$ in 2012 as compared to $24.9 \%$ in 2004 if the child behaves in a violent manner. Furthermore, we see that all these attitudes are significantly associated with corporal punishment in the 2012 survey; that is, the more the mothers agree that corporal punishment is necessary, acceptable, and effective, the more they report its use toward children.

Finally, certain particularities are found in the results regarding the trends of the level of sensitivity to the impact of family violence. On the one hand, the percentage of mothers thinking that corporal punishment administered to children by their parents can often or very often cause physical injuries (33\% in 2012) fell significantly, not only in comparison to 2004 (40.6\%), but also in comparison to 1999 (35.8\%). On the other hand, in both the 2012 and the 2004 surveys, about three quarters of mothers (76\%) thought that psychological problems often or very often develop in children who have been repeatedly yelled or sworn at, a result that is higher than that obtained in 1999 (72.9\%). In brief, in comparison to the first survey, mothers are less sensitive to the physical consequences of corporal punishment and more sensitive to the psychological impact of repeated episodes of psychological aggression.

\section{DISCUSSION}

Results of the third edition of the survey conducted in 2012 show that more than one third (34.7\%) of children experienced some form of corporal punishment during the course of the year, the most common form being a slap on the hand, arm, or leg (26.2\%). In general, this rate is similar to the rate reported in the most recent American (Theodore et al., 2005; Taylor, Manganello, Lee, \& Rice, 2010) and Canadian (Lee et al., submitted) studies. Furthermore, we note its continual and significant decrease over 13 years; the annual prevalence rates dropped from $47.7 \%$ in 1999 to $42.9 \%$ in 2004 and then to $34.7 \%$ in 2012 . This represents an important decrease in the number of child victims each year, regardless of their age group. Documented on the basis of three measurement times, and supported by the attitude changes and the decrease in the use of repeated corporal punishment, this result most probably reflects a real change in the use of corporal punishment toward children in Quebec. Such change has also been observed on the national level (Fréchette \& Romano, 2012) and in American surveys (Zolotor et al., 2011).

This decrease in the annual report of corporal punishment, either solely or repeatedly, could be linked to the socioeconomic changes seen in Quebec's population of families with minor children living at home. In fact, comparison of family profiles in the three surveys shows major differences with respect to the mothers' level of education, age at the child's birth, perceived and current income, and employment status (see Table 2). The social support index also shows that mothers felt they had more support in 2012 as compared 
Table 3

Associations Between Parental Attitudes and Prevalence of Corporal Punishment in 2012

\begin{tabular}{|c|c|c|}
\hline & $\begin{array}{c}\text { Corporal } \\
\text { punishment }\end{array}$ & $p$ \\
\hline & $\%$ & \\
\hline \multicolumn{3}{|c|}{ In general, Quebec parents are too soft on their children } \\
\hline Strongly or somewhat agree & 35.3 & ** \\
\hline Strongly or somewhat disagree & 31.9 & \\
\hline \multicolumn{3}{|l|}{ It's wrong for parents to slap their children } \\
\hline Strongly or somewhat agree & 29.4 & *** \\
\hline Strongly or somewhat disagree & 38.9 & \\
\hline \multicolumn{3}{|c|}{ Some children need to be slapped so that they will learn a lesson } \\
\hline Strongly or somewhat agree & 54.1 & *** \\
\hline Strongly or somewhat disagree & 31.2 & \\
\hline \multicolumn{3}{|c|}{ There should be a law allowing parents to use force to discipline their children } \\
\hline Strongly or somewhat agree & 45.2 & *** \\
\hline Strongly or somewhat disagree & 33.2 & \\
\hline \multicolumn{3}{|c|}{ Spanking is an effective way of disciplining children } \\
\hline Strongly or somewhat agree & 49.1 & $* * *$ \\
\hline Strongly or somewhat disagree & 33.2 & \\
\hline \multicolumn{3}{|c|}{ It would be acceptable for a parent to slap a child if the child has provoked it } \\
\hline Strongly or somewhat agree & 54.8 & $* * *$ \\
\hline Strongly or somewhat disagree & 32.0 & \\
\hline \multicolumn{3}{|c|}{ It would be acceptable for a parent to slap a child if the child is being disobedient } \\
\hline Strongly or somewhat agree & 55.9 & ${ }^{* * *}$ \\
\hline Strongly or somewhat disagree & 32.1 & \\
\hline \multicolumn{3}{|c|}{ It would be acceptable for a parent to slap a child if the child is being violent } \\
\hline Strongly or somewhat agree & 48.8 & ${ }^{* * * *}$ \\
\hline Strongly or somewhat disagree & 32.2 & \\
\hline \multicolumn{3}{|c|}{ Children can be physically injured after their parents administered corporal punishment } \\
\hline Often or very often & 32.9 & ${ }^{* * *}$ \\
\hline Occasionally or rarely/never & 40.6 & \\
\hline \multicolumn{3}{|c|}{ Children can develop psychological problems that can last a long time because their } \\
\hline Often or very often & 36.6 & \\
\hline Occasionally or rarely/never & & \\
\hline
\end{tabular}

Note. ${ }^{* *} p<.01 .{ }^{* * *} p<.001$. 
to the support they reported receiving in 2004. As a whole, these factors, known to be risk factors for corporal punishment (Gershoff, 2002; Woodward \& Fergusson, 2002), could partially explain the behavioural change observed over 13 years. Another hypothesis for explaining the change over this time period involves the social policies implemented to support children (e.g., child care; Gouvernement du Québec, 2008) and the universal prevention programs for assisting the more disadvantaged families (e.g., Triple-P, Services Intégrés en Périnatalité et pour la Petite Enfance).

Certain observations are drawn from the analysis of the attitudes toward corporal punishment as documented in the survey (Table 3 ). First, we systematically note a significant association of parental attitudes and attributions with corporal punishment behaviours toward the child. This finding corresponds to the scientific literature, which has largely confirmed the role of favourable attitudes toward violent forms of discipline toward children (Dufour, Clément, Chamberland, \& Dubeau, 2011; Jackson et al., 1999; Machado, Gonçalves, Matos, \& Dias, 2007; Rodriguez, 2010) and more particularly, the role of attributing blame to the child to justify corporal punishment (Fortin et al., 2000; Rodriguez \& Sutherland, 1999). The 2004 survey results also showed that favourable attitudes helped to explain the report of physical violence, even when controlling for the effect of other individual, familial, and social variables, and regardless of the parent's gender (Clément et al., 2005). There is also a great deal of documentation illustrating the role of attitudes in the intergenerational cycle of parental violence. Victims of parental violence, including corporal punishment, have a greater tendency to adopt pro-violence attitudes as adults (Ateah \& Parkin, 2002; Bensley et al., 2004; Clément \& Chamberland, 2009; Gagné, Tourigny, Joly, \& Pouliot-Lapointe, 2007), especially if these behaviours are judged appropriate or deserved (Bell \& Romano, 2012). We can easily hypothesize that a significant percentage of parents who supported violence in the survey were subjected to such behaviours by their parents. Previous analyses from the first two surveys (1999 and 2004) confirmed this hypothesis with both mothers (Clément \& Bouchard, 2005; Clément \& Chamberland, 2009) and fathers (Clément, Dufour, Chamberland, \& Dubeau, 2009; Jamal, Dufour, \& Clément, 2011). Unfortunately, the 2012 survey did not document violence occurring during the respondents' childhood, so such analyses cannot be reproduced.

The social learning operating within a child who is a victim of violence or of corporal punishment is tainted by his or her perception of the legitimacy of the punishment received. Such punishment is still legally regulated in Canada. While in 2012, there were fewer mothers who supported a law allowing the reasonable use of force in disciplining children (11.6\%) as compared to 2004 (15.7\%), we might think that the current legal framework normalizes corporal punishment and facilitates its acceptance as a childrearing practice. Studies show that in Canada, public approval of Section 43 of the Criminal Code foresees the intention to use corporal punishment among adults from the general population (Bell \& Romano, 2012; Toronto Public Health, 2006). Nevertheless, we know that the majority of individuals, whether or not they are parents, are unaware of the Supreme Court's decision to allow corporal punishment only under certain conditions (e.g., children aged between 2 and 12 years old, without the use of objects, on an instructional basis; Durrant, Sigvaldason, \& Bednar, 2008; Toronto Public Health, 2006).

Another observation concerns the changes noted over 13 years with respect to parental attitudes. In certain attitudes favouring corporal punishment, we have witnessed a significant decrease between the 
survey's third cycle and its first or second ones. For example, fewer mothers think that some children need to be slapped to learn to behave and that spanking is effective in disciplining children. Such a decrease in attitudes supporting corporal punishment has recently been observed in Canada (Bell \& Romano, 2012). Considering the explanatory role of attitudes in the use of interpersonal violence, these results confirm the changes observed with respect to the decrease of corporal punishment prevalence rates. The similarities observed in these results and in those from other recent studies support the hypothesis that there has been a real change in attitudes and practices within the population (Bell \& Romano, 2012; Fréchette \& Romano, 2012). Furthermore, if the social desirability bias was able to influence the mothers' statements, it would also indicate changes in norms within the population. We know a disapproval of corporal punishment will lead to avoidance of this behaviour. The cognitive conflict caused by a divergence between opinion and representation, on the one hand, and adopted behaviours on the other, must necessarily return to a state of equilibrium through the modification of one of the two functions (Chamberland, 2003).

However, some of the results obtained with respect to specific attitudes are surprising. First, results indicate that there were more mothers who think that Quebec's parents are too soft on their children in 2012 and 2004 (about 80\%) than there were 13 years ago (76.7\% in 1999). This observation could indicate that Quebec mothers are seeking more guidance in teaching their children; while violence is becoming less accepted, mothers still want to remain equally firm or strict. Moreover, the children of mothers who consider parents too soft experience a greater percentage of the corporal punishment $(35.3 \%)$ than those of mothers who do not share this opinion (31.9\%). In this respect, it is possible that the repertoire of knowledge of disciplinary measures other than corporal punishment is not widespread enough or that such alternative measures are not seen as sufficient or effective, at least in certain situations. Parent education programs that teach discipline strategies have proven to be effective and must become as integral a part of a preventive approach (Sanders, 2010; Scholer, Hamilton, Johnson, \& Scott, 2010; Wiggins, Sofronoff, \& Sanders, 2009) as programs that focus on changing attitudes (Ateah \& Durrant, 2005; Robinson, Funk, Beth, \& Bush, 2005).

Finally, another surprising result concerns the level of sensitivity to the impact of violence on the child. Although the results show that in 2004 and 2012, the vast majority of mothers (76\%) tend to think that children can often or very often develop psychological problems when they are repeatedly yelled or sworn at, sensitivity to the physical impact of corporal punishment follows a different tangent. It is possible that parents increasingly see corporal punishment as a minor form of violence, a form to which they are resorting less and less frequently. It is also possible that they conceived corporal punishment as having a potential psychological impact on the child. This would then lead to a lower percentage of mothers in $2012(33 \%)$ who think, as was the case in 1999 (35.8\%), that pain or physical injuries can result from corporal punishment as compared to the percentage reported in 2004 (40.6\%). This observation may not prove so much that there has been a general lessening of empathy but that there has been a change in the perception of corporal punishment as a disciplinary measure, once more confirming the change in social norms that currently seems to be occurring in Quebec with respect to this disciplinary practice. It may also indicate that parents are more aware of the psychological impact of violence on the child. Moreover, when associated with reports of corporal punishment, the results are much as we would expect, namely that the less empathy the parents exhibit, the more they report the use of corporal punishment on their child, thus confirming the importance of empathy in the prevention of violence against children (Clément \& Chamberland, 2009; Stith et al., 2009). 


\section{CONCLUSION}

This paper shows that a growing majority of mothers disapproves of corporal punishment in childrearing and reports that it has been used less and less with children over the past decade. This trend confirms results that have been previously obtained (Clément \& Chamberland, 2007) and indicates that there is an increasingly negative societal norm regarding corporal punishment. This is reflected in certain legal and policy provisions that have been implemented in Quebec over the past decade (e.g., child care, family policy) and underscores the relevance of the debate on abolishing Section 43 of Canada's Criminal Code.

Furthermore, the results of the survey clearly reveal the need to help parents with their childrearing strategies. Although corporal punishment meets with society's disapproval, childrearing that is too permissive is regarded in a similar fashion. Parents seem to distinguish between the need for parental authority as a requirement for fostering child development and the use of violence in conflict management. Promoting alternative methods of firmness in discipline that do not involve violence should mobilize concerned stakeholders in the coming years, the goal being to optimize child protection and development — an important issue in Quebec society.

\section{REFERENCES}

Afifi, T. O. (2011). Child maltreatment in Canada: An understudied public health problem. Canadian Journal of Public Health, 102(6), 459-462.

Afifi, T. O., Mota, N. P., Dasiewicz, P., MacMillan, H. L., \& Sareen, J. (2012). Physical punishment and mental disorders: Results from a nationally representative US sample. Pediatrics, 130(2), 1-11. doi:10.1542/peds.2011-2947

American Academy of Pediatrics. (1998). Guidance for effective discipline. Pediatrics, 101(4), 723-728.

Ateah, C. A., \& Durrant, J. (2005). Maternal use of physical punishment in response to child misbehavior: Implications for child abuse prevention. Child Abuse \& Neglect, 29, 169-185.

Ateah, C. A., \& Parkin, C. M. (2002). Childhood experiences with, and current attitudes toward, corporal punishment. Canadian Journal of Community Mental Health, 21(1), 35-46.

Bavoleck, S. J. (1984). Handbook for the adult-adolescent parenting inventory (AAPI). Schaumburg: Family Development Associates.

Bell, T., \& Romano, E. (2012). Opinions about child corporal punishment and influencing factors. Journal of Interpersonal Violence, 27(11), 2208-2229. doi:10.1177/0886260511432154

Bensley, L., Ruggles, D., Simmons, K. W., Harrise, C., Williams, K., Putvin, T., \& Allene, M. (2004). General population norms about child abuse and neglect and associations with childhood experiences. Child Abuse \& Neglect, 28(12), 1321-1337. doi:10.1016/j.chiabu.2004.07.004

Berlin, L. J., Ispa, J. M., Fine, M. A., Malone, P. S., Brooks-Gunn, J., Brady-Smith, C., . . Bai, Y. (2009). Correlates and consequences of spanking and verbal punishment for low-income White, African American, and Mexican American toddlers. Child Development, 80(5), 1403-1420.

Bernard, P. M., \& Lapointe, C. (1995). Mesures statistiques en épidémiologie. Sainte-Foy: Presses de l'Université du Québec. Canadian Paediatric Society. (2004). Une discipline efficace auprès des enfants. Pediatric Child Health, 9(1), 37-41.

Caron, J. (1996). L'Échelle de provisions sociales: une validation québécoise. Santé mentale au Québec, 21(2), 158-180.

Chamberland, C. (2003). Violence parentale et violence conjugale. Des réalités plurielles, multidimensionnelles et interreliées. Sainte-Foy: Presses de l'Université du Québec.

Clément, M.-È. (2011). La violence physique envers les enfants: Le cas particulier de la punition corporelle. Revue de Psychoéducation, 40(1), 121-134.

Clément, M.-È., Bernèche, F., Chamberland, C., \& Fontaine, C. (2013). La violence familiale dans la vie des enfants du Québec, 2012. Sainte-Foy: Institut de la Statistique du Québec. 
Clément, M.-E., \& Bouchard, C. (2005). Predicting the use of single versus multiple types of violence towards children in a representative sample of Quebec families. Child Abuse \& Neglect, 29(10), 1121-1139.

Clément, M.-E., Bouchard, C., Jetté, M., \& Laferrière, S. (2000). La violence familiale dans la vie des enfants du Québec, 1999. Québec: Institut de la Statistique du Québec.

Clément, M.-E., \& Chamberland, C. (2007). Physical violence and psychological aggression towards children: Fiveyear trends in practices and attitudes from two population surveys. Child Abuse \& Neglect, 31(9), 1001-1011.

Clément, M.-E., \& Chamberland, C. (2009). The role of parental stress, mother's childhood abuse and perceived consequences of violence in predicting attitudes and attribution in favor of corporal punishment. Journal of Child and Family Studies, 18(2), 163-171.

Clément, M.-È., Chamberland, C., Côté, L., Dubeau, D., \& Beauvais, B. (2005). La violence familiale dans la vie des enfants du Québec, 2005. Sainte-Foy: Institut de la Statistique du Québec.

Clément, M.-È., Dufour, S., Chamberland, C., \& Dubeau, D. (2009). Description et analyse des attitudes et attributions paternelles favorables à la punition corporelle. Canadian Journal of Behavioural Science, 41(1), 11-21. doi: $10.1037 / \mathrm{a} 0013564$

Coalition Canadienne pour les droits des enfants. (2009). L'intérêt supérieur de l'enfant : signification et mise en application au canada. Toronto: Coalition Canadienne pour les droits des enfants.

Cutrona, C. E. (1984). Social support and stress in the transition to parenthood. Journal of Abnormal Psychology, 93(4), 378-390.

Daro, D. (1998). Public opinion and behaviors regarding child abuse prevention: 1998 survey. Washington, DC: The Center on Child Abuse Prevention Research.

Daro, D., \& Gelles, R. J. (1992). Public attitudes and behaviors with respect to child abuse prevention. Journal of Interpersonal Violence, 7(4), 517-531.

Dufour, S., Clément, M.-È., Chamberland, C., \& Dubeau, D. (2011). Child abuse in a disciplinary context: A typology of violent family environments. Journal of Family Violence, 26(8), 595-606. doi:10.1007/s10896-011-9394-0

Durrant, J. E., \& Ensom, R. (2004). Les punitions corporelles et les enfants Feuillet du CEPB\#7F. Ottawa: Ligue pour le bien-être de l'enfance du Canada.

Durrant, J. E., Sigvaldason, N., \& Bednar, L. (2008). What did the Canadian public learn from the 2004 Supreme Court decision on physical punishment? International Journal of Children's Rights, 16(2), 229-247. doi: $10.1163 / 157181808 \times 301818$

Durrant, J. E., Trocmé, N., Fallon, B., Milne, C., \& Black, T. (2009). Protection of children from physical maltreatment in Canada: An evaluation of the Supreme Court's definition of reasonable force. Journal of Aggression, Maltreatment \& Trauma, 18(1), 64-87.

Emery, R., E., \& Laumann-Billings, L. (1998). An overview of the nature, causes, and consequences of abusive family relationships: Toward differentiating maltreatment and violence. American Psychologist, 53(2), 121-135.

Fortin, A., Chamberland, C., \& Lachance, L. (2000). La justification de la violence envers l'enfant: un facteur de risque de violence. Revue internationale d'éducation familiale, 4(2), 5-34.

Fortin, A., \& Lachance, L. (1996). Mesure de la justification de la violence envers l'enfant: étude de validation auprès d'une population québécoise. Les Cahiers Internationaux de Psychologie Sociale, 31, 91-103.

Fréchette, S., \& Romano, E. (2012). Change in the prevalence of corporal punishment over a 14-yer period in a representative sample of Canadian parents. Edmonton: International Society for the Study of Behavioural Development.

Gagné, M.-H., Tourigny, M., Joly, J., \& Pouliot-Lapointe, J. (2007). Predictors of adult attitudes toward corporal punishment of children. Journal of Interpersonal Violence, 22(10), 1285-1304.

Gershoff, E. T. (2002). Corporal punishment by parents and associated child behaviors and experiences: A meta-analytic and theoretical review. Psychological Bulletin, 128(4), 539-579.

Gershoff, E. T., Lansford, J. E., Sexton, H. R., Davis-Kean, P., \& Sameroff, A. J. (2012). Longitudinal links between spanking and children's externalizing behaviors in a national sample of White, Black, Hispanic, and Asian American families. Child Development, 83(3), 838-843. doi:10.1111/j.1467-8624.2011.01732.x

Gouvernement du Québec. (2008). La politique familiale au Québec: vise, portée, durée et rayonnement. Quebec City: Conseil de la famille et de l'enfance, Gouvernement du Québec.

Grogan-Kaylor, A. (2004). The effect of corporal punishment on antisocial behavior in children. Social Work Research, 28(3), 153-163. 
Institut de la Statistique du Québec. (2009). Données sociales du Québec: Édition 2009. Quebec City: Author. Institut de la Statistique du Québec, en collaboration avec l'Institut National de Santé Publique du Québec et le Ministère de la Santé et des Services Sociaux du Québec. (2011). Guide spécifique des aspects méthodologiques des données d'enquêtes sociosanitaires du Plan commun de surveillance - Enquête sur la santé dans les collectivités canadiennes cycles 1.1, 2.1, 3.1 et 2007-2008. Quebec City: Gouvernement du Québec.

Institut de la Statistique du Québec. (2013). Panorama des régions du Québec: Édition 2013. Quebec City: Author.

Jack, S. M. (2010). The role of public health in addressing child maltreatment in Canada. Chronic Diseases in Canada, 31(1), 39-44.

Jackson, S. J., Thompson, R. A., Christiansen, E. H., Colman, R. A., Wyatt, J., Buckendahl, C. W., ... Peterson, R. (1999). Predicting abuse-prone parental attitudes and discipline practices in a nationally representative sample. Child Abuse \& Neglect, 23(1), 15-29.

Jamal, F., Dufour, S., \& Clément, M.-È. (2011). Liens entre la légitimité perçue de la violence subie dans l'enfance de pères québécois et violence actuelle vécue par leurs enfants dans la famille. Revue de Psychoéducation, 40(2), $175-190$.

Larzelere, R. E. (2000). Child outcomes of nonabusive and customary physical punishment by parents: An updated literature review. Clinical Child and Family Psychology Review, 3(4), 199-221.

Machado, C., Gonçalves, M., Matos, M., \& Dias, A. R. (2007). Child and partner abuse: Self-reported prevalence and attitudes in the north of Portugal. Child Abuse \& Neglect, 31(6), 657-670.

Mulvaney, M., \& Mebert, C. (2007). Parental corporal punishment predicts behavior problems in early childhood. Journal of Family Psychology, 21(3), 389-397.

Oldershaw, L. (2002). A national survey of parents of young children. Toronto: Invest in Kids.

Organisation des Nations-Unies. (2006). La violence contre les enfants. Geneva: Étude du secrétaire général des Nations-Unis.

Organisation Mondiale de la Santé. (2002). Rapport mondial sur la violence et la santé. Geneva: Author.

Paolucci, E. O., \& Violato, C. (2004). A meta-analysis of the published research on the affective, cognitive, and behavioral effects of corporal punishment. Journal of Psychology, 138(3), 197-221.

Paquette, D., Bigras, M., \& Crepaldi, M. A. (2010). La violence: Un jugement de valeur sur les rapports de pouvoir. Revue de Psychoéducation, 39(2), 247-276.

Robinson, D. H., Funk, D. C., Beth, A., \& Bush, A. M. (2005). Changing beliefs about corporal punishment: Increasing knowledge about ineffectiveness to build more consistent moral and informational beliefs. Journal of Behavioral Education, 14(2), 117-139.

Rodriguez, C. M. (2010). Parent-child aggression: Association with child abuse potential and parenting styles. Violence and Victims, 25(6), 728-741.

Rodriguez, C. M., \& Sutherland, D. (1999). Predictors of parents' physical disciplinary practices. Child Abuse \& Neglect, 23(7), 651-657.

Sanders, M. R. (2010). Adopting a public health approach to the delivery of evidence-based parenting interventions. Canadian Psychology, 51(1), 17-23. doi:10.1037/a0018295

Scholer, S. J., Hamilton, E. C., Johnson, M. C., \& Scott, T. (2010). A brief intervention may affect parents' attitudes toward using less physical punishment. Community Health, 33(2), 106-116.

Stith, S. M., Liu, T., Davies, L. C., Boykin, E. L., Alder, M. C., Harris, J. M., . . Dees, J. E. M. E. G. (2009). Risk factors in child maltreatment: A meta-analytic review of the literature. Aggression and Violent Behavior, 14(1), 13-29. doi:10.1016/j.avb.2006.03.006

Straus, M. A. (2008). The special issue on prevention of violence ignores the primordial violence. Journal of Interpersonal Violence, 23(9), 1314-1320.

Straus, M. A., Hamby, S. L., Finkelhor, D., Moore, D. W., \& Runyan, D. K. (1998). Identification of child maltreatment with the Parent-Child Conflict Tactics Scales: Development and psychometric data for a national sample of American parents. Child Abuse \& Neglect, 22(4), 249-270.

Straus, M. A., \& Paschall, M. J. (2009). Corporal punishment by mothers and development of children's cognitive ability: A longitudinal study of two nationally representative age cohorts. Journal of Aggression, Maltreatment \& Trauma, 18(5), 459-483. doi:10.1080/10926770903035168 
Taylor, C. A., Manganello, J. A., Lee, S. J., \& Rice, J. C. (2010). Mothers' spanking of 3-year-old children and subsequent risk of children's aggressive behavior. Pediatrics, 125(5), 1-11.

Theodore, A. D., Chang, J. J., Runyan, D., Hunter, W., Bangdiwala, S. I., \& Agans, R. (2005). Epidemiologic features of the physical and sexual maltreatment of children in the Carolinas. Pediatrics, 115(3), 331-337.

Toronto Public Health. (2006). National survey of Canadian's knowledge on the law on physical punishment of children. Toronto: Author.

Tourigny, M., Gagné, M.-H., Joly, J., \& Chartrand, M. (2006). Prévalence et cooccurrence de la violence envers les enfants dans la population québécoise. Revue Canadienne De Santé Publique, 97(2), 109-113.

Tourigny, M., Hébert, M., Joly, J., Cyr, M., \& Baril, K. (2008). Prevalence and co-occurrence of violence against children in the Quebec population. Australian \& New Zealand Journal of Public Health, 32(4), 331-335.

Trocmé, N., Fallon, B., MacLaurin, B., Sinha, V., Black, T., Fast, E., ... Holroyd, J. (2010). Étude canadienne sur l'incidence des signalements de cas de violence et de négligence envers les enfants-2008: Données principales. Ottawa: Agence de la santé publique du Canada.

Wiggins, T. L., Sofronoff, K., \& Sanders, M. R. (2009). Pathways Triple P-Positive Parenting Program: Effects on parent-child relationships and child behavior problems. Family Process, 48(4), 517-530.

Woodward, L. J., \& Fergusson, D. M. (2002). Parent, child, and contextual predictors of childhood physical punishment. Infant and Child Development, 11(3), 213-235.

Zolotor, A. J., \& Puzia, M. E. (2010). Bans against corporal punishment: A systematic review of the laws, changes in attitudes and behaviours. Child Abuse Review, 19(4), 229-247.

Zolotor, A. J., Theodore, A. D., Runyan, D. K., Chang, J. J., \& Laskey, A. L. (2011). Corporal punishment and physical abuse: Population-based trends for three-to-11-year-old children in the United States. Child Abuse Review, 20(1), $57-66$. 